ESTUDOS LITERÁRIOS 


\title{
OF INFINITE REGRESS: PARADIGMS UNBROKEN IN J.-K. HUYSMANS'S A REBOURS*
}

\author{
Richard-Laurent Barnett**
}

\begin{abstract}
If there were no eternal consciousness in a man, if at the foundation of all there lay only a wildly secthing power, which, writhing with obscure passions produced everything that is insignificant, if a bottomless void never satiated lay hidden beneath all - what then would life be but utter despair?

Sören Kierkegaard
\end{abstract}

o postulate a poetic of desire is per force and irrevocably to invoke the comportments of difference. The discursive and performative interdependence of desire and difference, their utter impartibility, pre-empts in fact the lithe inventions of post-modernism by which such co-presence is, in a sense, anachronistically valorized. Still, if traditionalists have taken stock of the pre-Derridean pairing, if they have dispassionately acknowledged that desire is the philologiêifference defeesis falls yet wide of the mark, as it draws with excessive dispatch to a shuddering halt, leaving unturned and unsaid the

* I spize this opportunity to express gratitude to the Frederick A. Treuhaft Foundation for the valuable research support provided $i$ the preparation of this text.

** Graduate Dean and Treuhaft Professor of the Marygrove College (Detroit, MI). 
BARNETT, R.-L. Of infinite regress: paradigms...

irremediability, indeed the subversiveness of this indissoluble two-ness. More enigmatically still, embedded in the symbiotic coupling of quest and otherness is the promise of incompatibility, the pre-inscribed certitude of inadequacy, the inverted assurance of demise. Whence the deconstructive imperative.

From the early Renaissance to the present, for Rabelais as for RobbeGrillet, for René as for Roquentin, for Phèdre and Folantin, Gaston and Godot, Jourdain and Genet, for Candide, Emma, and surely for Bardamu, the call for difference breeds inevitably a radical encounter with failure. Untamed, bungled, ill-devised, impolitic desire cedes its place to defeat - not gratuitously, as if by choice, but definitionally, inviolably, a-priorily. And the text becomes - as consequence - a cipher - metaphysical and narratological - of just that utter undoing, of that pre-ordained, ignominious decease. The illegitimacy of the enterprise is its very substance. A stance of hope, an act of quest are patently reified only to be dismounted, subsumed, over-determined by the impossibility of repletion. In such a revisionist optic, Lamartine's desperate plea for the anchoring of life, Molière's call for the containment of mis-fired ambition, Beckett's cry for an end to entropy constitute metonymic representations of the same losing game, like spectacles of inglorious perdition, what Shakespeare aptly dubbed "that lame and impotent conclusion." Signification thereby derives from the space, the interstitial gap disjoining the inscribed clamor for, and postulated belief in, triumph and the concomitant ineluctability of eternal wantingness. To sustain such a duplicitous vision, literarity must accede to the ruses of semblance. And unfailingly - it does.

The multiplex problematic of text as posture, as set-up, as subterfuge, in itself a compelling and tangled one, sires repercussions all the more contrived and extirpative in Huysmans's $A$ rebours (see Gasché, Gaviria, Lloyd, Porter). For here, a narrative engages in ludic, unvoiced dialogue with the self; in a kind of auto-annulling proliferation and excoriation of matter un-meaning. So do we witness a pscudo-challenge from within, a masquerade in ambuscade, an involuted confabulation heaved to the second power.

On the surface, allegedly, Des Esseintes's decadent discourse translates a genuine, if forever thwarted, pursuit of alterity: a tortuous code, respitlessly pushing back the boundaries of speech, struggling to render what is most inexpressible in thought, what is most vague and elusive in form, straining to transcribe the illusive confidences of neurosis, the dying confessions of passion grown depraved, and the strange hallucinations of obsession turned madness, alas, the ultimate utterance of the Word, summoned to final destination and driven to its last hiding-place. Perceived in this light, the protagonist's palpable desire (son désir pulsionnel) would strike as indistinguishable from its literary 
homologues — precedents and successors alike. On closer scrutiny, however, we discover that such parity runs counter to textual truth. The novelist lays a baited trap before the reader, entertains a meta-dramatic hoax (see Przybos). For, quite apart from his paradigmatic siblings, Huysmans's leading man, the backsliding recidivist here center-staged collaborates with undaunted consciousness in the playact: he is in control, attuned to the failures to be wrought, eager to live out the seeming-ness of each engineered permutation: "Après les fleurs factices singeant les véritables fleurs, il voulait des fleurs naturelles imitant des fleurs fausses." (p. 101)

From the outset, as early as the novel's pre-scriptural notice, the narrative is skillfully skewed so as to betray a conspiracy from within. The protagonist's gamesmanship, his exploitative knowingness is semioticized in the guise of an invective against desire's impossible fulfillment:

Son mépris de l'humanité s'accrut; il comprit enfin que le monde est, en majeure partie, composé de sacripants et d'imbéciles. Décidément, il n'avait aucun espoir de découvrir chez autrui les mêmes aspirations et les mêmes haines, aucun espoir de s'accoupler avec une intelligence qui se complât, ainsi que la sienne, dans une studieuse décrépitude, aucun espoir d'adjoindre un esprit pointu et chantourné tel que le sien... (p. 85-86)

Markers of deflation and depletion saturate the text; a language of cognition points - incipiently, as it were - to the disingenuousness of all subsequent deceits. But - one must hasten to add - ephemerally, delusively, anti-climactically, for the saturation, the trilogy of no-hope avowals (ancun espoir de découvrir, aucun espoir de s'accoupler, aucun espoir d'adjoindre) is expressly mis-guided, gives way, not to surrender, not to cessation, but several periods hence, to a forged renovation of spirit, to a slickly revitalized (if predictably short-lived) sense of enablement. The poem's "fond illusion" is in place; hopelessness must be cloaked, default masked if the recitation of desire is to perdure. So emerges Des Esseintes's tryst with womanhood, the re-cast myth of Narcissus (now turned romancier), abruptly, untransitionally recounted

1 All references are drawn from the Folio edition. 
BARNETT, R,-L. Of infinite regress: paradigms...

in terse, almost auto-parodic prose - as though to engulf the reader in a post-Nietzschean, pre-Kristevian tale of woe:

Une seule passion, la femme, cût pu le retenir dans cet universel dédain qui le poignait, mais celle-là était, elle aussi, usée. Il avait touché aux repas charnels, avec un appétit d'homme quinteux, affecté de maladie, obsédé de fringales et dont le palais s'émousse et se blase vite; au temps où il compagnonnait avec les hobereaux, il avait participé à ces spacieux soupers où des femmes soûles se dégrafent au dessert et battent la table avec leur tête; il avait aussi parcouru les coulisses, tâté des actrices et des chanteuses, subi, en sus de la bêtise innée des femmes, la délirante vanité des cabotines; puis il avait entretenu des filles dejà célèbres et contribué à la fortune de ces agences qui fournissent, moyennant salaire, des plaisirs contestables: enfin, repu, las de ce luxe similaire, de ces caresses identiques, il avait plongé dans les bas-fonds, espérant ravitailler ses désirs par le contraste, pensant stimuler ses sens assoupis par l'excitante malpropreté de la misère... Quoi qu'il tentât, un immense ennui l'opprimait. II s'acharna, recourut aux périlleuses caresses des virtuoses, mais alors sa santé faiblit et son système nerveux s'exacerba... alors, ce fut la fin: comme satisfaits d'avoir tout épuisé, comme fourbus de fatigue, ses sens tombèrent en léthargie, l'impuissance fut proche. (p. 86-87)

A surfeit of narratological weaponry is here harnessed so as to undermine the specter, the faux dehors, the ignis fatuus of truth. The text is turned upon itself, and so posed, fashions a lexicon of insuperability: cach "etymon" which, in isolation, might be assigned a positive value is contextually countered by an auto-annulling term of devalorization. More crucially still, the passage moves from one to another set of signs that are encodedly if insidiously equivalent, each a substitute for the last, a resemblance of it, through a series of transformations in which no element is the first or the pivot around which all others turn or the end at which they might recede. Within this hypogrammatic system, where language is internally, analogically re-semanticized, a jaded palate equals depraved mistresses equals commonplace caresses equals exhausted desires equals flagging senses (see Barnett, Cogny, Gaillard, Levin, Miller, Riffaterre). Whatever the operative metaphor, an underlying absence of triumph, un-invertable downfall is everywhere intoned - rhetorically and always provisionally. It may well be, in fact, that provisionality is the name of the game, a touchstone, 
BARNETT, R.-L. Of infinite regress: paradigms...

a pre-requisite for continuance, the quintessential feature of structuration. Displacement, disarticulated shifts textualize the allegory of other. The poeticization of despair, a chain of obliterated possibilities, a momentary song of disenchantment are, as example, indeterminately reframed and re-fashioned as an ode to solitude:

Déjà il rêvait à une thébaide raffinée, à un désert confortable, à une arche immobile et tiède où il se réfugierait loin de l'incessant déluge de la sottise humaine... Ses idées de se blottir, loin du monde, de se calfeutrer dans une retraite, d'assourdir, ainsi que pour ces malades dont on couvre la rue de paille, le vacarme roulant de l'inflexible vie, se renforcèrent. (p. 86-87)

For the skeptic resistant to that which is subjacent, an aphoristic aside sets the record straight - and on this occasion unequivocally so: "En effet, il suffit qu'on soit dans l'impossibilité de se rendre à un endroit pour qu'aussitôt le désir d'y aller vous prenne" (p. 88). (A man has only to know he cannot get to a certain spot to be scized with desire to go there. $)^{2}$ The veil is drawn, the seal broken, the curtain raised. One disinterred mini-maxim has spilled the textual beans, thrown off all disguise, disclosed the wily devices underwriting this factitious score. Mimesis cedes its place to semiosis: the metaphorization of otherness craved is imbued with meaning only as it veers toward, and is determined by, self-eradication.

If we can ferret our way through and out of this messiness, we find ourselves yet impacted: we are, after all, only at the pre-text's end, at the novel's leading edge, not nearly in medias res, but at the point of origination. As chapter one kicks off, the artifice has been uncloaked, the tale told, the die cast. ${ }^{3}$ Which makes of the prologue at once a checkpoint and a caveat, at once a self-sustaining entity and an indigent annex, a kind of thwarted embryo, a mis-placed clone of the substance it marginalizes. With this in mind, Des Esseintes, no longer the poet's prey or proxy, must be henceforth embraced as a scholar of literary art, a drafter of texts, an exegete whose stuff of life is encompassed quite literally by

2 The formula is reminiscent of, and central to, the Pascalian diathesis.

3 The thomy problem of "pre-textuality" is examined by Bamett, Genette; for a more specifically Huysmansian application, consult Kingcaid. 
BARNETT, R.-L. Of infinite regress: paradigms...

his role as self-appointed muse. Always in control, gleefully seized by, and author of, his own liminality, pathologically and metaphorically ahead of the game, exemplarily daring as he drags us, in the words of Havelock Ellis, "by our hair and feet down the worm-eaten staircase of terrified Syntax," the famed (if misread) duc of Fontenay ceased never to look into, to disserate upon, the scripts before him, a score as such hyper-meta-textual by genesis and in substance. And in this sense, yet at the very margins of discourse, one is duly tempted to posit that the alleged point of inauguration, the proemial overture consummates, discharges, exhausts the script before it is played out.

In fact, the sixteen chapters that would purportedly unfold the fixations of the narration's central figure, are displaced and, as de Man would astutely have it, deconstructed by the pre-textual event. The process of expansion, of accretion is one by which beforeness is recapitulated, antecedents re-staged unhaltingly. One cannot even allude to "variants"; for the sameness of each reiterative sequence proves tautological, hauntingly redundant.

Everywhere imitative passages erupt-bluntly undifferent. So that in chapter nine, the lure and the lore of floral exotica are transmuted into ciphers of nothingness. The reversion to insupportable despair is prescriptive, imperative:

[...] ces simili-douches n'enrayaient nullement la marche de la névrose; tout au plus éprouvait-il un soulagement de quelques houres, chèrement payé du reste par le retour des accès qui revenaient à la charge, plus violents et plus vifs... Son ennui devint sans borne; la joie de posséder de mirobolantes floraisons était tarie; il était déjà blasé sur leur contexture et sur leurs nuances[...] (p. 206)

While in chapter eleven, solitude and silence, so ardently quested, invoke unsustainable distress: "Une fois de plus, cette solitude si ardemment enviée et enfin acquise, avait abouti à une détresse affreuse; ce silence qui lui était autrefois apparu comme une compensation des sottises écoutées pendant des ans, lui pesait maintenant d'un poids insoutenable." (p. 239-240)

And on the novel's penultimate page, at the end of the end, aphoristic appeasements are decomposed; language is stripped of sense - as Des Esseintes slakes into a state of inconvertible insentience: 
Il appelait à l'aide pour se cicatriser, les consolantes maximes de Schopenhauer; il se répétait le douloureux axiome de Pascal: "L’âme ne voit rien qui ne l'afflige quand elle y pense," mais les mots résonnaient, dans son esprit, comme des sons privés de sens; son ennui les désagrégeait, leur ôtait toute signification, toute vertu sédative, toute vigueur effective et douce. (p. 360)

The hegemon of a self-styled poetic replaces and defuses the very possibility of content as it obliquely and obtusely center-stages the lying-ness of the text's ostensible symptomology (see Kristeva).

We, the readers, summoned to, and entrapped within, a universe of doomful refrain, meet with lyrics designed expressly to retell, reword, recast, recite, rehearse a discourse of likeness (see Bernheimer, Cirillo, Loomis, Vilcot, Ziegler). Yet this anomalous absence of progression, regression, transgression seems to have stumped even the critical stars. Rather their invocation of decadent diversity gives way to an exegetical vision of always something new, variegation, autre chose, discreteness, idiosyncrasy (e.g., Antosh, Audoin, Brunel). While in fact, each apparent adjuvant simulates, mimics, smacks of, replicates patterns engendered in the preface, patterns no sooner birthed than abrogated, patterns which inscribe and reinscribe indelibly - if prematurely the pretenses of alterity. The novel is assembled as, and sustained by, a series of tropes rescinded as the non-figurability of otherness calls for inscription by proxy. Whereby episodic images of implacable sameness are commissioned to emblematize the impossibility of else and co-extensively le principe zérologique de l'écriture. 4

Fumaroli is not far amiss when he contends that "Huysmans n'a pas seulement résumé, immortalisé les torpeurs, les langueurs, les névroses vénéneuses et perverses du siècle finissant." In effect, "le plaisir du texte" (the pleasure of the text), if we might appropriate a neo-Barthesian epithet, resides, not in the contrivances of illusory quests, not in lavish eccentricities, nor even in the predestined promise of failure, but rather in the de-signifying power of representation. A writ of subversion and of subtraction, a guise upon the page, an ever reconstituted fiction, and a dismantling commentary from within upon the text's ingrown deceits, $A$ rebours prototypes the posturings of paradigms unbroken, the perils of infinite regress.

4 The term is attributable to, and borrowed from, Kristeva. 
BARNETT, R.-L. Of infinite regress: paradigms...

\section{ABSTRACT}

The multiplex problematic of text as posture, as set-up, as subterfuge, in itself compelling and tangled one, sires repercussions all the more contrived and extirpative in Huysmans's A rebours. For here, the narrative engages in ludic, unvoiced dialogue with the self; in a kind of auto-annulling proliferation and excoriantion of matter un-meaning. So do we witness a pseudo-challenge from within, a masquerade in ambuscade, an involuted confabulation heaved to the second power.

Key-words: Huysmans, Joris-Karl, A rebours, ludism.

\section{RESUMO}

A problemática multiplexa do texto como postura, construção, subterfúgio, em si mesma compelativa e emaranhada, cria repercussões ainda mais engenhosas e extirpadoras em $A$ rebours, de Huysmans. Aqui a narrativa entra num diálogo lúdico e mudo com o Eu numa espécie de proliferação e escoriação auto-anulativa de in-significado. Assim, testemunhamos um pseudo-desafio de dentro, uma mascarada de tocaia, uma confabulação intrincada alçada ao segundo poder.

Palavras-chave: Huysmans, Joris-Karl, A rebours, ludismo.

\section{WORKS CITED}

ANTOSH, Ruth B. Reality and illusion in the novels of J.-K. Huysmans. Amsterdam: Rodopi, 1986.

AUDOIN, Philippe. Huysmans. Paris: Veyrier, 1985.

BARNETT, Richard-Laurent. En guise d'avant-propos. L'Esprit Créateur, n. 27, p. 1-2, 1987.

. Herméneutique et marginalité. Rivista di Letterature Moderne e Comparate 58,

p. 212-239, 1999.

. La chair devenue livre. European Studies, p. 137-150, 1998.

. Of word and world withered: imperiled representation in Zola's Nana; Textualities, p. 84-98, 1998.

. Pascal's proemial tropes, L'Esprit Créateur, n. 27, p. 39-49, 1987. 
BARNETT, R.-L. Of infinite regress: paradigms...

Sémantique du déclin zolienne. Degrés: Revue de Synthèse à Orientation Sémiologique, n. 36, p. 178-191, 1997.

BARTHES, Roland. Le plaisir du texte. Paris: Seuil, 1973.

BERNHEIMER, Charles. L'exorbitant textuel: castration et sublimation chez Huysmans, Romantisme, n. 14, p. 104-113, 1984.

BRUNEL, Pierre. (Ed.) Huysmans. Paris: L'Herne, 1985.

CIRILLO, Valeria De Gregorio. Double registre et négativité dans la description huysmansienne. Annali Istituto Universitario Orientale - Napoli - Sezione Romanza, $\mathrm{n}$. 25, p. 651-670, 1983.

COGNY, Pierre. De l'écriture à l'Ecriture. Saint-Centré: Téqui, 1987.

DE MAN, Paul. Allegories of reading. New Haven and London: Yale University Press, 1979.

FUMAROLI, Marc. (Ed.) Huysmans, A rebours. Paris: Folio, 1977. p. 17.

GAILLARD, Françoise. A rebours ou l'inversion des signes. In: L'esprit de la décadence I. Nantes: Minard, 1980.

GASCHÉ, Rodolphe. The falls of history: Huysmans's A rebours. Yale French Studies, n. 74, p. 183-204, 1980.

GAVIRIA, Ricardo Cano. J.-K. Huysmans, o el absoluto en busca de autor. Quimera, n. 2, 1980. p. 53-56.

GENETTE, Gérard. Seuils. Paris: Seuil, 1987.

HUYSMANS, Joris-Karl. A rebours. Paris: Folio, 1977.

KINGCAID, Renée A. Amazing grace: A rebours twenty years after. L'Esprit Créateur, n. 27, p. $68-78,1987$.

KRISTEVA, Julia. Distance et anti-représentation. Tel Quel, 1966. p. 51.

LLOYD, Christopher. French naturalism and the monstrous: J.-K. Huysmans and $A$ rebours. Durham University Journal, n. 81, p. 111-121, 1988.

LOOMIS, Jeffrey B. Of pride and the fall: the allegorical A rebours, Nineteenth-Century French Studies, n. 12-13, p. 147-161, 1984.

LEVIN, Mark S. Huysmans and the void. Cambridge: Cambridge University Press, 1996. MILLER, J. Hillis. When is a primitive like an orb? In: CAWS, Mary Ann (Ed.). Textual analysis: some readers reading. New York: MLA, 198. p. 167-181.

PASCAL René: Pensées. Paris: Garnier Flammarion, 1976.

PORTER, Laurence. Huysmans's A rebours: the psychodynamics of regression. American Imago, n. 44, p. 51-65, 1987.

PRZYBOS, Julia. Concerning a physiological geometry: the metaliterary content of J.-K. Huysmans's Sac au dos. L'Esprit Créateur, n. 25, p. 105-114, 1985.

RIFFATERRE, Michael. Production du texte. Paris: Seuil, 1979. Semiotics of poetry. Bloomington: Indiana University Press, 1978.

VILCOT, Jean-Pierre. Huysmans décadent ou l'horreur du vide. In: L'Esprit de la décadence. v. 1. Nantes: Minard, 1980.

ZIEGLER, Robert E. De-compositions: the aesthetics of distancing in J.-K. Huysmans, Forum for Modern Language Studies, n. 22, p. 365-373, 1986. 